\title{
Didymocarpus nepalensis (Gesneriaceae), a new species from eastern Nepal
}

\author{
Adhikari B. * \& M. Möller \\ Royal Botanic Garden Edinburgh, 20 A Inverleith Row, Edinburgh EH3 5LR, Scotland, UK \\ *E-mail: badhikari@rbge.org.uk
}

\begin{abstract}
A new species of Gesneriaceae from eastern Nepal, Didymocarpus nepalensis Bh.Adhikari \& Mich.Möller is described and illustrated. It is morphologically most closely allied to $D$. cinereus D.Don but differs by its well-developed stem, the absence of basal leaves and less deeply divided calyx. A detailed description, colour photographs, line drawings are provided and the morphological differences of relevant species are discussed.
\end{abstract}

Keywords: Didymocarpus, Endemism, Himalayas, Nepal, Taxonomy.

\section{Introduction}

Didymocarpus Wall. belongs to the predominantly Old World subfamily Didymocarpoideae (previously Cyrtandroideae) in Gesneriaceae. In the latest classification, the genus was placed in tribe Trichosporeae subtribe Didymocarpinae (Weber et al., 2013). The genus is characterised by a herbaceous habit, few to many flowers in pairflowered pedunculate cymes, pair of free bracts, free or connate sepals, tubular corolla, one pair of stamens included inside the corolla tube, capitate stigma and a longitudinally dehiscent capsule.

Weber and Burtt (1998["1997"]) divided the genus into two sections: (1) Didymocarpus sect. Didymocarpus which includes all species except those from South Thailand and Malay Peninsula, (2) Didymocarpus sect. Elati Ridl., with species from South Thailand and Malay Peninsula. According to the most recent study, the genus Didymocarpus

Received: 24.12.2019; Revised \& Accepted: 20.03 .2020 Published Online: 11.05 .2020 comprises over 100 species (Möller, 2019; Souvannakhoummane et al., 2019; Yang et al., 2019; Prasanna et al., this issue) distributed in the Himalayas (Nepal, Bhutan, Northeast India), Myanmar, South and Southwest China, Vietnam, Laos, Cambodia, Thailand, Malay Peninsula and North Sumatra (Weber \& Burtt, 1998[“1997”]; Möller et al., 2017).

The genus is most diverse in China, India and Thailand, with 35, 24 and 23 species recorded respectively (Wang et al., 1998; Nangngam \& Maxwell, 2013; Nangngam \& Middleton, 2014; Möller et al., 2017; Möller, 2019; Souvannakhoummane et al., 2019; Yang et al., 2019; Prasanna et al., this issue). Twelve species are reported from Nepal (Hara, 1982; Press et al., 2000), eight from Bhutan (Hilliard, 2001) and several from Myanmar, Malay Peninsula, Indonesia, Vietnam and Laos. The discovery of this species Didymocarpus nepalensis Bh.Adhikari \& Mich.Möller brings the total number of Didymocarpus species in Nepal to thirteen.

In Nepal, D. aromaticus Wall. ex D.Don (Fig. 1a), D. oblongus Wall. ex D.Don (Fig. 1b), D. pedicellatus R.Br. (Fig. 1c) and D. villosus D.Don (Fig. 1d) are commonly found species on moist ground in mid-hill forests. Other species, such as D. albicalyx C.B.Clarke (Fig. 1e), D. andersonii C.B.Clarke, D. cinereus D.Don (Fig. 1f), and D. pulcher C.B.Clarke are known from only few localities in eastern and central Nepal. The proposed new species $D$. nepalensis was collected from eastern Nepal, and is morphologically close to $D$. cinereus. The morphological differences between these two species are presented in Table 1. 

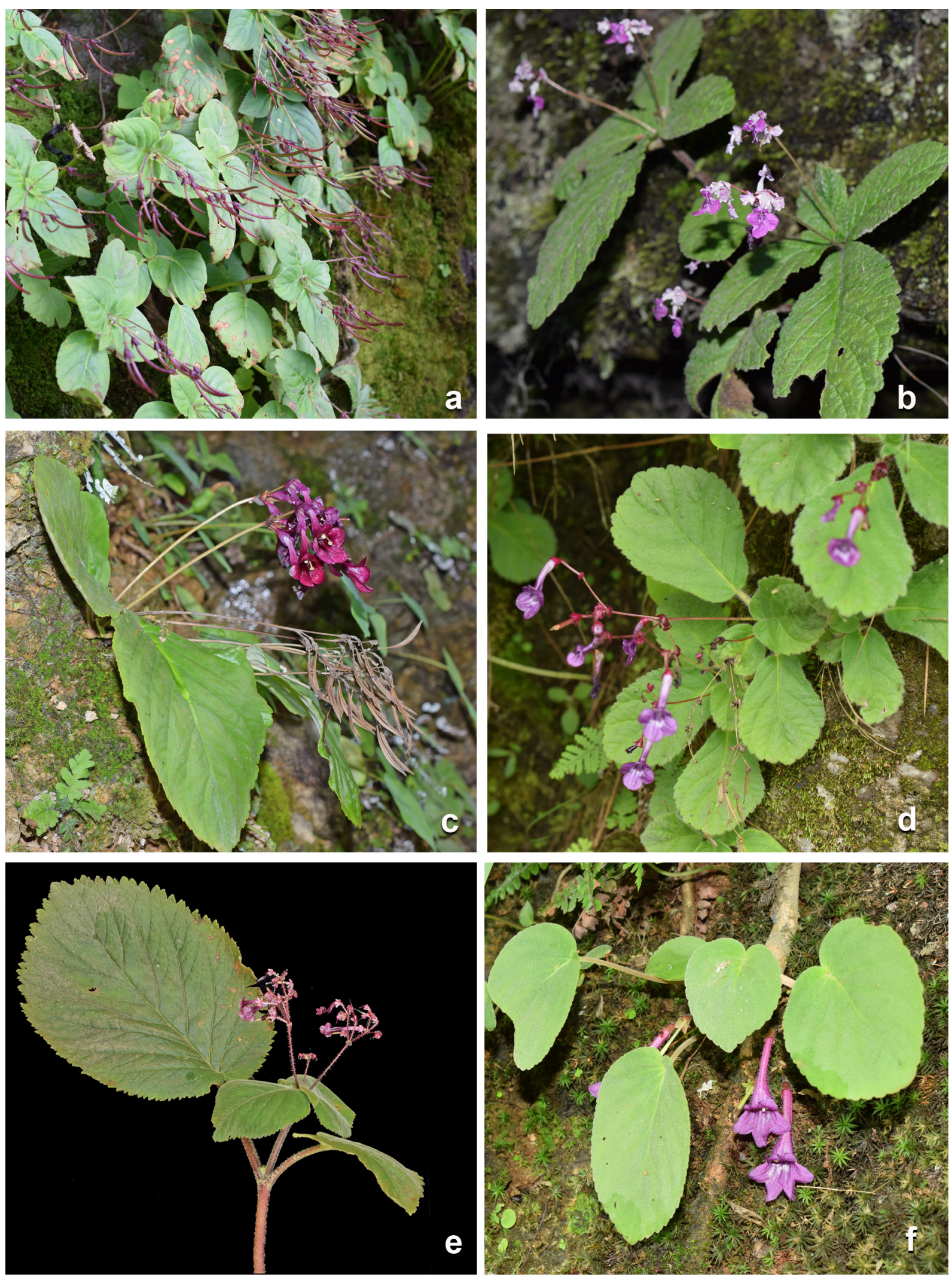

Fig. 1. Selected species of Didymocarpus found in Nepal: a. D. aromaticus Wall. ex D.Don; b. D. oblongus Wall. ex D.Don; c. D. pedicellatus R.Br.; d. D. villosus D.Don; e. D. albicalyx C.B.Clarke; f. D. cinereus D.Don; (photos by Bhaskar Adhikari). 


\section{Materials and Methods}

This study is based on field studies of wild populations of Didymocarpus in Nepal in 2014 and 2016 and on herbarium studies of specimens including type specimens from BM, E, K and KATH herbaria. Specimens of the proposed new species were checked against herbarium specimens and flora of adjacent regions. A conservation assessment for the new species was made using the criteria provided by IUCN (2019).

Didymocarpus nepalensis Bh.Adhikari \& Mich.Möller, sp. nov.

Figs. $2 \& 3$

Didymocarpus nepalensis is most similar to D. cinereus but can be distinguished by the absence of basal leaves ( $v s$. present), inflorescences shorter than the stems ( $v s$. equal to longer) and calyx lobes $1 / 4-1 / 3$ of the calyx tube ( $v$ s. half or more than half).

Type: NEPAL, Dhankuta district, Pakhribas Municipality, Bokre, 27.08.2014, $1829 \mathrm{~m}, B$. Adhikari, M. Kreuzer \& R. Basnet 13 (holo E!; iso KATH!).

Perennial herbs. Stems 7-17 cm long, appressed pubescent, hairs c. $0.1 \mathrm{~mm}$ long. Basal leaves absent, cauline leaves in lower half of the stem or near the middle in whorls of 3 or 4 , those in upper half of the stem of same size and shape (if present) opposite, isophyllous to anisophyllous, ovate-elliptic, $4-7 \times$ $0.8-5 \mathrm{~cm}$, base cordate, apex obtuse, margins crenate, surfaces appressed pubescent with yellow sessile glands; uppermost cauline leaves 2-4, opposite-decussate isophyllous to anisophyllous, $1-$ $3.5 \times 0.8-3 \mathrm{~cm}$, base cordate, apex obtuse, margins irregularly crenate, surfaces appressed pubescent with bright yellow sessile glands; petioles $1-14 \mathrm{~cm}$ long, uppermost leaves usually sessile or shortly petiolate. Inflorescences 2-6, axillary in uppermost cauline leaves, pair-flowered cymes, flowers 2-6 per cyme; peduncles $1-5 \mathrm{~cm}$ long; pedicels $0.5-1$ $\mathrm{cm}$ long, both glandular pubescent. Bracts in pair, free, ovate-lanceolate, 4.5-5 × 3-3.5 mm, densely glandular pubescent along margins and lower surface. Calyx dark purple, 5-7 mm, glandular pubescent with sessile glands; lobes 5 , triangular, $1 / 4-1 / 3$ of the length of the tube, $1-2 \times 1-1.5 \mathrm{~mm}$; tube $4-5 \mathrm{~mm}$ long. Corolla dark purple, $3-4 \mathrm{~cm}$ long, 2-lipped; upper lip 2-lobed, lobes ovatetriangular, 3-4 × 4-5 mm; lower lip 3-lobed, lobes ovate, 4-5 × 4-5.5 mm, glandular pubescent; tube infundibuliform, cylindric for $c .1 \mathrm{~cm}$ and gradually widening, slightly vertically compressed, appearing cylindrical from the side, opening oval. Stamens 2, inserted $2-3 \mathrm{~cm}$ from the base of the corolla; filaments 7-9 mm long, glabrous; anthers coherent, 3-4 $\times 1-2 \mathrm{~mm}$, sparsely hairy. Staminodes 3, unequal, two laterals 4-6 mm long, middle one 2$3 \mathrm{~mm}$ long. Disc cylindrical, $1.5-2 \mathrm{~mm}$ high, margins crenate. Pistils purplish green, $3-3.5 \mathrm{~cm}$ long; ovary cylindric, $2.5-3 \mathrm{~cm}$ long; style c. 0.5 cm long, glabrous; stigma capitate, slightly bilobed. Capsules 3-3.5 cm long, straight in relation to pedicel, valves straight to slightly curved, stipitate, glabrous. Seeds not seen.

Flowering \& fruiting: Flowering from June to August and fruiting from July to August.

Habitat: On moist mossy cliffs in south facing forests dominated by Alnus nepalensis D.Don.

Table 1. Morphological differences between D. nepalensis and D. cinereus

\begin{tabular}{|c|c|c|}
\hline Characters & D. nepalensis Bh.Adhikari \& Mich.Möller & D. cinereus D.Don \\
\hline Stems & 7-17 cm long, well developed, unbranched. & $\begin{array}{l}2-8 \mathrm{~cm} \text { long, } 1-4 \text { additional slender stems arising } \\
\text { from the axils of lower cauline leaves and/or basal } \\
\text { leaves. }\end{array}$ \\
\hline Leave & $\begin{array}{l}\text { Basal leaves absent, lower cauline leaves equal } \\
\text { or below the inflorescences, uppermost leaves } \\
\text { well developed, } 1-3.5 \times 0.8-3 \mathrm{~cm} \text {. }\end{array}$ & $\begin{array}{l}\text { Basal leaves present, basal and/or lower cauline } \\
\text { leaves overtopped the inflorescences, uppermost } \\
\text { cauline leaves much smaller, } 0.5-1.5 \times 0.5-1.5 \mathrm{~cm} \text {. }\end{array}$ \\
\hline Calyx & Calyx lobes $1 / 4-1 / 3$ of the length of the tube. & Calyx lobes more than half of the length of the tube. \\
\hline
\end{tabular}




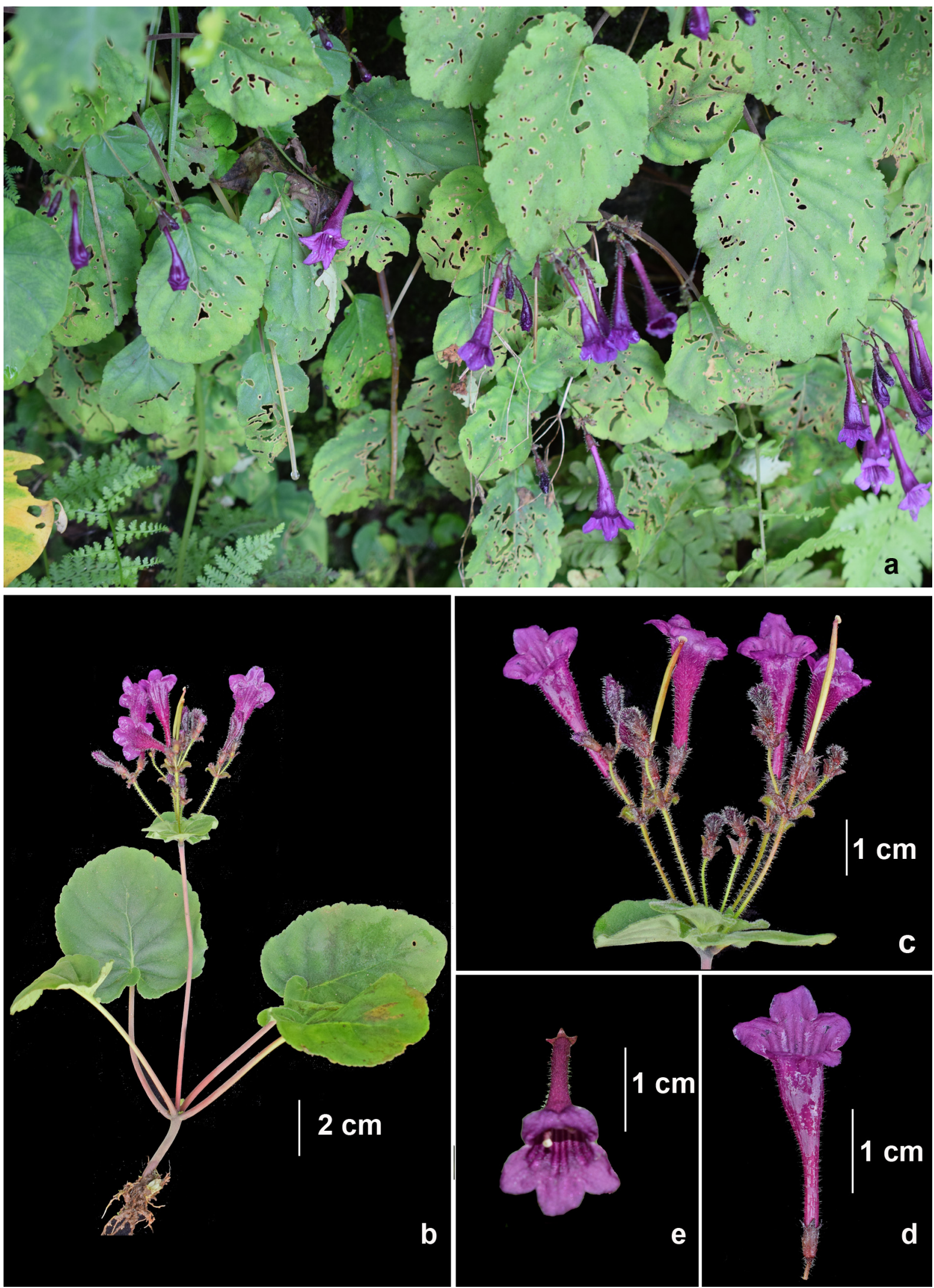

Fig. 2. Didymocarpus nepalensis Bh.Adhikari \& Mich.Möller: a. Habit; b. Flowering plant; c. Inflorescences; d. Flower-oblique side view; e. Flower-front view showing enantiostyly (photos by Bhaskar Adhikari). 


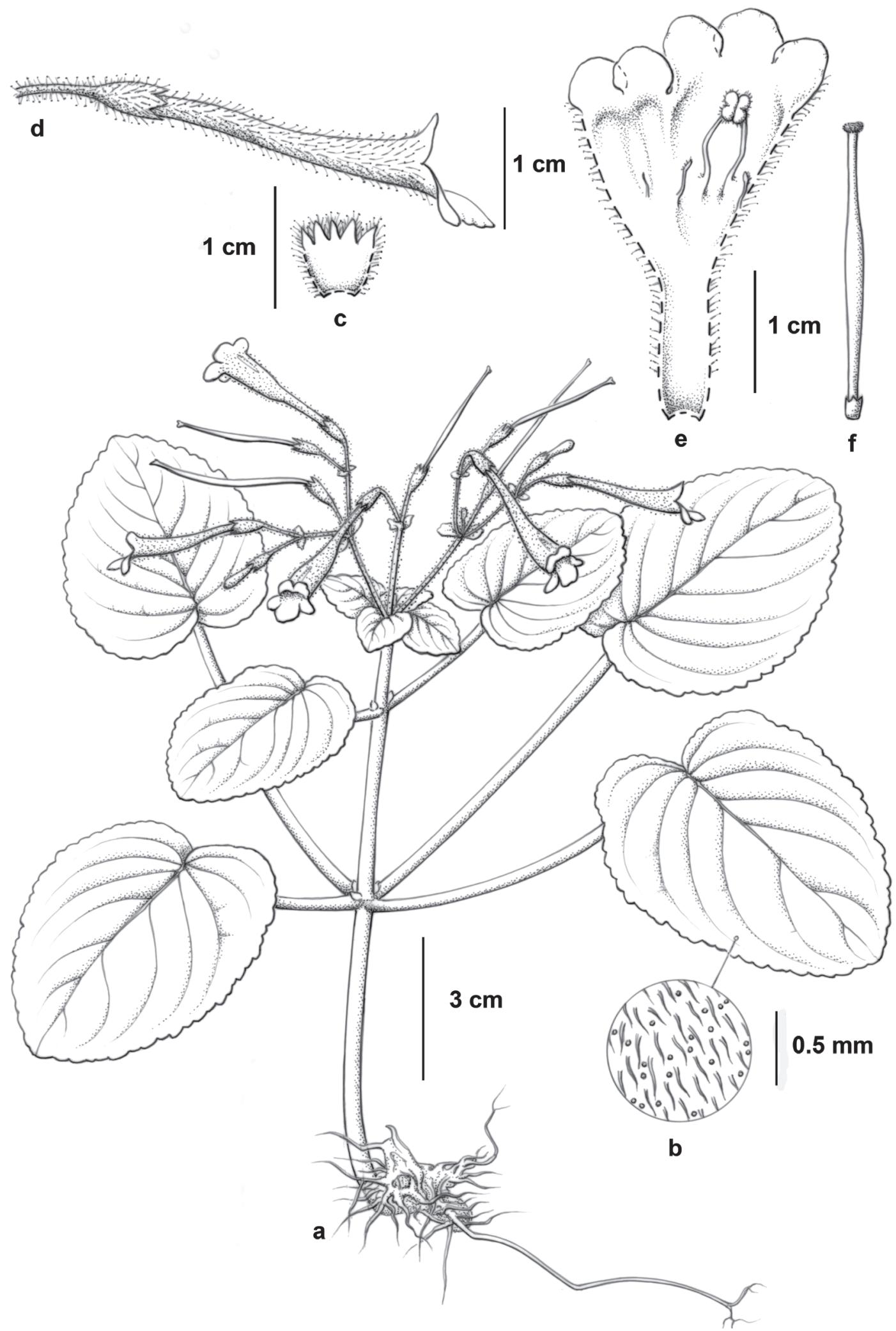

Fig. 3. Didymocarpus nepalensis Bh.Adhikari \& Mich.Möller: a. Habit; b. Leaf surface showing hairs and sessile glands; c. Opened calyx; d. Flower-lateral view; e. Opened corolla showing stamens and staminodes; f. Pistil (drawn by Claire Banks). 
Distribution: Eastern Nepal.

Specimen examined: NEPAL, Dhankuta district, Pakhribas Municipality, Bokre, 27.08.2014, 1829 m, B.Adhikari, M. Kreuzer \& R. Basnet 11 (E, KATH). Conservation status: Didymocarpus nepalensis is known from one locality with two small populations in Dhankuta district of East Nepal. Each population consists of around 20-30 mature individuals. More extensive collections from eastern and central Nepal from similar habitats are needed to confirm its conservation status. However, there exist some threats as the populations are located near to a road and some species of Didymocarpus are collected by the locals to make incense. At present, it is best to be categorised as Data Deficient (DD) until more information on its uses, threats and status of population numbers becomes available.

Notes: Several Didymocarpus species from Nepal and adjacent areas in India are similar to the new species and possess violet to purple corollas (Fig. 1). However, some have cylindric corolla tubes, such as, D. albicalyx (Fig. 1e), D. andersonii, D. macrophyllus Wall. ex D.Don, D. oblongus (Fig. 1b), D. primulifolius D.Don and D. villosus(Fig. 1d). Other species such as D. aromaticus (Fig. 1a), D. cinereus (Fig. 1f), D. pedicellatus (Fig. 1c), D. podocarpus C.B.Clarke and D. pulcher have similar infundibuliform corolla tubes but differ by other morphological characters: in D. pedicellatus the stem is very short (up to $1.5 \mathrm{~cm}$ ) or absent. D. aromaticus and $D$. podocarpus are easily distinguished from any other and the new species by the position of their leaves; in D. aromaticus leaves are distant and alternate in the lower part of the stem whereas in D. podocarpus all leaves are crowded towards the apex of the stem. D. pulcher differs by its tall stems up to $45 \mathrm{~cm}$, and 2-lipped calyx, and D. cinereus (Fig. 1f) differs by the characters given in Table 1. Similar to many other Didymocarpus species, but not all (e.g., Nangngam \& Maxwell, 2013; Nangngam \& Middleton, 2014; Pandey et al., this issue; Prasanna et al., this issue), D. nepalensis shows reciprocal enantiostyly, the deflection of the style and stamens to the left or right in opposite directions (Fig. 2e).

\section{Acknowledgements}

We would like to thank the curators of BM, E, K and KATH for giving access to their herbarium collections. We greatly appreciate Claire Banks for her line drawings. Thanks are also due to Vinita Gowda and Prasanna N. Shrungeshwara for their input prior to the preparation of the manuscript. We are also thankful to anonymous reviewers for their valuable suggestions. The Royal Botanic Garden Edinburgh is supported by the Scottish Government's Rural and Environment Science and Analytical Services Division.

\section{Literature Cited}

HARA H. 1982. Gesneriaceae. In: HARA H., CHATER A.O. \& L.H.J. WILLIAMS (eds.), An enumeration of the flowering plants of Nepal. Volume 3. British Museum (Natural History), London. pp. 133-136.

HILLIARD O.M. 2001. Gesneriaceae. In: GRIERSON A.J.C. \& D.G. LONG (eds.), Flora of Bhutan: including a record of plants from Sikkim. Volume 2(3). Royal Botanic Garden Edinburgh. pp. 1296-1330.

IUCN STANDARDS AND PETITIONS COMMITTEE 2019. Guidelines for Using the IUCN Red List Categories and Criteria. Version 14. Prepared by the Standards and Petitions Committee. Available at: http:// www.iucnredlist.org/documents/RedListGuidelines.pdf. (Accessed on 10.12.2019)

MÖLLER M., NAMPY S., JANEESHA A.P. \& A. WEBER 2017. The Gesneriaceae of India: Consequences of updated generic concepts and new family classification. Rheedea 27(1): 23-41. https://dx.doi.org/10.22244/ rheedea.2017.27.1.5

MÖLLER M. 2019. Species discovery in time: An example from Gesneriaceae in China. Guangxi Sciences 26(1): 116. https://doi.org/10.13656/j.cnki.gxkx.20190307.002

NANGNGAM P. \& J.F. MAXWELL 2013. Didymocarpus (Gesneriaceae) in Thailand. Gardens' Bulletin Singapore 65(2): 185-225.

NANGNGAM P. \& D.J. MIDDLETON 2014. Five new species of Didymocarpus (Gesneriaceae) from Thailand. Thai Forest Bulletin (Botany) 42: 35-42. https://li01.tcithaijo.org/index.php/ThaiForestBulletin/article/view/ 24910

PANDEY S., KANTHRAJ A.S., RANA T.S. \& K.N. NAIR 2020. Notes on a new geographic record, rediscovery and lectotypification of some Indian Didymocarpus (Gesneriaceae). Rheedea this issue. https://dx.doi.org/ 10.22244/rheedea.2020.30.01.11 
PRASANNA N.S., LIU D.T., SARYAN P., DUAN S.Z., CAI L. \& V. GOWDA 2020. Didymocarpus sinoindicus (Gesneriaceae), a new species from India and China. China. Rheedea this issue. https://dx.doi.org/10.22244/ rheedea.2020.30.01.07

PRESS J.R., SHRESTHA K.K. \& D.A. SUTTON 2000. Annotated Checklist of the Flowering Plants of Nepal. The Natural History Museum, London.

SOUVANNAKHOUMMANE K., SOULADETH P., TAGANE S. \& C.J. YANG 2019. Flora of Nam Kading National Protected Area VI: Didymocarpus middletonii (Gesneriaceae), a new species from limestone. Edinburgh Journal of Botany 76(1): 45-54. https://doi.org/10.1017/ S0960428618000264
WANG W.T., PAN K.Y., LI Z.Y., WEITZMAN A.L. \& L.E. SKOG 1998. Didymocarpus. In: WU Z.Y. \& P.H. RAVEN (eds.), Flora of China. Volume 18. Science Press, Beijing and Missouri Botanical Garden Press, St. Louis. pp. 349-358.

WEBER A. \& B.L. BURTT 1998[“1997”]. Remodelling of Didymocarpus and associated genera (Gesneriaceae). Beiträge zur Biology der Pflanzen 70(23): 293-363.

WEBER A., CLARK J.L. \& M. Möller 2013. A new formal classification of Gesneriaceae. Selbyana 31(2): 68-94.

YANG B., DING H.B., FU K.C., YUAN Y.K., YANG H.Y., LI J.W., ZHANG L.X. \& Y.H. TAN 2019. Four new species of Gesneriaceae from Yunnan, Southwest China. PhytoKeys 130: 183-203. https://doi.org/ 10.3897/phytokeys.130.34001 